\title{
Paradoxical Analysis of the Existence of the Indonesian Archipelagic Sea Lane Against the Ideal of the World Maritime Axis
}

\author{
Siti Merida Hutagalung ${ }^{1 *}$ and Ruth Hanna Simatupang ${ }^{1}$ \\ ${ }^{1}$ International Relation Study Program, University of Kristen Indonesia, Jakarta, Indonesia
}

\begin{abstract}
Indonesian Archipelago (ALKI) towards the ideals of the world maritime axis launched by Jokowi. The search for data and interviews confirms that ALKI is contrary to the concept of the world maritime axis. The simple premise is that the maritime will always be present in the foreign sea traffic activities as a result of Indonesia's desire to become an open country (free sea). It also shows an insult to the sovereignty of a nation that aspires to be the world's maritime axis. Using Marine Strength Theory by Alfred T. Mahan, Jean Bodin's concept of sovereignty to examine the contradictions of the existence of ALKI in conceptualizing the world's maritime axis, the trend of results shows that first, the existence of ALKI actually endangers the aspirations of the world maritime axis; second, the archipelagic insights described in ALKI contradict the archipelagic insights implicit in Indonesia's maritime doctrine; third, ALKI divides maritime forces that must be united (unity); fourth, Indonesia is at the level of civilization that is not ready to become the world's maritime axis; fifth, ALKI based on UNCLOS 1982 contradicts the concept of sovereignty respected by the Indonesian people as the dignity of the nation.
\end{abstract}

\section{Introduction and literature review}

Indonesia has long been known as a maritime country. However, in the era of colonialism the concept was changed for the benefit of the colonial government [1]. During the period of colonialization, the Indonesian way of thinking was led to a concept of European-style understanding, where the sea and all its activities and potential were no longer a top priority. The concept of maritime land was changed to heartland, in the opinion of Halford

Mackinder, if you want to dominate the world, you must master your heart first [2] and for that we need ground forces that support. This is a grand strategy of European nations to drive the perspective of the Indonesian people to focus on the formation of land forces and ultimately not interfere with the development of European marine fleets. This concept transforms Indonesia into an agrarian country. Since that time the daily life of the Indonesian people depends on the results of agriculture and plantations.

\footnotetext{
**Corresponding author: meridasiti@yahoo.co.id
} 
However, in 1944 Indonesia unilaterally declared that this country is an archipelagic country as outlined in the Djuanda Declaration. In 1958 Indonesia officially declared the concept of an archipelago at the first International Sea Law conference in Geneva. Based on the Djuanda Declaration, the function of the sea was returned as the main focus of the Indonesian struggle. The Djuanda Declaration also affirmed that land, sea, sea floor, air and all wealth are in the same territory as Indonesia. [3] This means that Indonesia adheres to the principles of an archipelagic state. [4] The consequence of this statement is that all seas between islands are the territory of the Republic of Indonesia and not free areas. Despite receiving rejection from a number of countries, in 1982 Indonesia gained international recognition through the United Nations Convention on the Law of the Sea in Montego Bay, Jamaica. Furthermore, the Djuanda Declaration became the basis for the establishment of the third UN marine legal convention.

The policies made by the Old Order, New Order and Reform era governments, oriented economic development on land or agricultural management. This situation changes in the era of Jokowi, in which the government declares Indonesia as the World Maritime Axis / PMD. The idea is formulated into five pillars by rebuilding maritime culture as a manifestation of the territory jurisdiction. Jokowi's idea to restore the glory of Indonesia as a maritime country seemed to be inconsistent with the policy of the archipelagic sea lanes as the realization of the obligations of the island nation which made a number of Indonesian waters into international waters and caused Indonesia to be open to foreign trade vessels.

Previous writings from Ismah Rustam published in the Indonesian Journal Perspective Volume 1 Number 1 (January-June): 1-21 with the title: the Encounter of ALKI in Comprehending Indonesia's Ideas as a World Maritime Axis, explaining the security threats in the three ALKI's lines. The writing is an encounter to comprehend the Jokowi's PMD ideas.

\subsection{State Sovereignty and Sea Sovereignty}

Sovereignty is twofold, namely external sovereignty (independence) and internal sovereignty (state supremacy). Sovereignty shows the ownership status of a country in a territorial area or what is called territorial sovereignty. Sovereignty that comes from the word superanus means top [5] which means that power is owned by the State. Starke argued that sovereignty is the same as independence which is at the same time a function of a State. [6] Sovereignty can be equated with exclusive authority or freedom to carry out various state activities in accordance with their interests, provided that such activities or policies do not conflict with the interests of other countries or international law. [7]

Territorial sovereignty is sovereignty in implementing power management / exclusively owned by the State. The state has full authority in its territory to exercise its rights and enforce its national law. [7] Almost all countries have sovereignty on land, sea and air including Indonesia. Especially for Indonesia the sea area is larger than land and air.

The concept of sovereignty in the sea recognizes two streams, the first concept of mare liberum by Hugo Grotius (Netherlands) and the concept of mare clausum by John Shelden (England). The concept of mare liberum emphasizes freedom on the high seas. The concept of mare clausum means the sea is closed. These two legal concepts are intended to respond to coastal states' claims for maritime zones. The claim was also born from the practice of shipping monopolies carried out by Spain and Portugal which caused conflict with Britain and the Netherlands. These countries want the sea to be owned at a distance along the cannon eruption (3 miles).

The issue of sovereignty at sea was only agreed upon by the international community after a series of international conferences which were held from 1957 to 1982 with the enactment of the United Nation Convention on Law of The Sea 1982/ UNCLOS 1982. 
UNCLOS 1982 divides maritime zones into: internal waters, archipelagic waters, territorial sea, contiguous zones, Exclusive Economic Zone, continental shelf, high seas and the areas. UNCLOS also protects a country's national interests in the territorial waters and air above it. Recognition of the sea sovereignty has a very significant influence to Indonesia's territorial sea.

According to Bynkershoek, all states that want to have its sovereignty over their territorial sea must have the power to conduct surveillance of the sea areas under their control [8]. Therefore, Indonesia is also demanded to do the same thing, which should carry out supervision and management of the sea.

\subsection{Indonesia's Sea Lane Passage}

In accordance with Article 51 of the Convention on the Law of the Sea 1982: archipelagic states must respect neighboring countries when passing in the archipelagic waters. In order to follow up these regulations Indonesia has set several regulations in the maritime and sea regulations, which can be seen in Law No. 6 of 1996 regarding Indonesian Waters and Government Regulation No. 37 of 2002 regarding the Rights and Obligations of Foreign Vessels and Aircrafts in Implementing the Right to Pass the Archipelagic Waters. This provision is stipulated as an obligation of all archipelagic states towards the interests of the international community.

There are only 7 archipelagic sea lanes which are located in Egypt (Suez Canal), South America (Panama Canal), Spain and Morocco (Gibraltar Strait) and four others are located in Indonesia, namely: ALKI I is in the Malacca Strait, ALKI II in the Sunda Strait, ALKI III in the Makassar-Lombok Strait and ALKI IV in the Ombai Strait and Water which are still under planning.

The division of the archipelagic sea lanes poses various security threats in Indonesia's waters, among others: terrorism, human trafficking, smuggling, piracy, illegal fishing et cetera. With the entrance and exit doors to and from Indonesian waters, the level of national security needs to be the government's main concern, specifically in the application of strict legal instruments and the readiness of reliable and firm human resources to deal with crimes.

\subsection{Jokowi's Maritime Axis Regime}

The idea of creating Indonesia as a global maritime axis / PMD was delivered by President Jokowi before the international community at the East Asia Summit meeting in Nay Pwi Tau, Myanmar. PMD is carried out through 5 steps: first, rebuilding the maritime culture; second, managing and safeguarding natural resources with sea food sovereignty through the development of the fishing industry; third, the development of infrastructure and maritime connectivity by building sea toll, deep sport, logistics, shipping and marine tourism; Fourth, increasing cooperation with other states which have direct borders to overcome the problem such as fish theft, violations of sea sovereignty, sea border disputes, piracy and marine pollution; Fifth, implementing maritime diplomacy in order to develop cooperation amongst countries regarding maritime and eliminate sources of conflict such as illegal fishing, maritime violations and others.

\section{Objective of the Study}

The object of this study is about the sovereignty of Indonesia in the sea where ALKI regarded as a decision which would reduce the sovereignty of the Indonesian archipelago and also threatens security along ALKI. This Jokowi's program in rebuilding maritime culture and 
sea empowerment for the benefit of the national economy develops and builds connectivity as if reflecting the opposition (resistance) of public opinion about the reduction of Indonesian sovereignty. However in reality the program can indeed be considered to reduce Indonesia's sovereignty.

\section{Methodology}

The study on these issues and data were analyzed by implementing qualitative research methods and juridical normative method. Data were collected using secondary data such as books, legislation, journals, mass media, research results and seminars or discussions that deals and discuss related topics. Data sources were obtained mostly from the marine ministry library and the Navy's office.

\section{Discussion}

Based on the above matters and related articles on this matter (Article 1 paragraph 1, paragraph 3 and 8, Law No. 6 of 1996 concerning Indonesian Waters in conjunction with Government Regulation No. 37 of 2002 concerning Rights and Obligations of Ships, Aircraft Foreign Air in Executing Archipelagic Sea Traffic Rights) as well as according to international sea law expert, Hasyim Djalal, a maritime country is not the same as an island nation. A maritime country is a country that is able to exploit its marine potential even though the country may not have many seas like a coastal country. In this case the country must have technological capabilities, knowledge, equipment etc. to manage and utilize the sea in its space, natural wealth and strategic location. [9] In addition, it is known that Indonesia's waterways are among the busiest in the world so that trade through sea lanes is expected to increase by around 44\% in 2020 and will reach twice as much in 2031. [10] Therefore Jokowi's invitation to restore Indonesian sea sovereignty as a whole is considered to be in accordance with the contents of the article above and the concept of the maritime state referred to by Hasyim Djalal.

\section{Conclusion}

In order to maintain the sea sovereignty and the concept of maritime shaft to the welfare of Indonesian society, thus ALKI become a safe trajectory islands that need to be considered and acted on the following matters:

a. Safety, security and surveillance along ALKI Indonesia should be a priority to defend the sovereignty and jurisdiction. The threat of maritime security will continue to occur if Indonesia as the owner of sovereignty and authority has not been able to implement its national legal certainty.

b. When security is guaranteed and surveillance along ALKI can be applied, then five Jokowi governance agenda can be implemented.

c. Indonesia needs to be established Maritime Information Center/IMIC which is the integration of surveillance equipment from the information center of the Ministry/Agency and naval military command center.

d. Building a seabed sensor system using Coastal Acoustic Tomography (CAT) technology with the concept of Seabed Sonar operation.

e. Development of the Sea ToI (APTL) Shipping Channel with the aim of increasing Maritime Domain Awareness (MDA) to realize shipping security between ports throughout Indonesia, as well as supporting sustainable logistics and national transportation systems. 
f. Utilizing US strategy (Re-balancing Strategy) and the Chinese strategy (Strategic Silk Road One Belt One Road). Both of the country's strategies must be utilized as best as possible by Indonesia in order to improve development in the fields of economy and defense. [11].

\section{Reference}

1. G. O. Tuathail, S. Dalby, P. Routledge, The Geopolitics Reader (Routledge: London, 1998).

2. K. McPherson, The Indian Ocean : A History of People and The Sea (OxfordUniversity Press, Delhi, 1993)

3. H. Djalal, Regime of Archipelagic States ( Manila, 2011)

4. D. Puspitawati, ijil 8, 4, Pp. 693-715 (2011).

5. M. Kusumaatmadja, E. Agoes, Pengantar Hukum Internasional (Alumi, Bandung, 2010 )

6. J.G. Starke Pengantar Hukum Intrernasional (Sinar Grafika, Jakarta, 2008).

7. M. S. Buana, Hukum Internasional Teori dan Praktiknya (Radjawai Press, Jakarta, 2011)

8. M. Kusumaatmadja, Bunga Rampai Hukum Laut (Binacipta, Bandung, 1978)

9. Victor S, Indonesia Menuju Poros Maritim Dunia, Pusat Pengkajian Penglahan Data dan Informasi (P3DI), Sekretariat Jenderal DPR RI,VI (1),(21), Jakarta.

10. Review of Maritime Transport Tahun 2008, United Nations Confrence On Trade Development (UNTAD, 2008)

11. http://www.ui.ac.id/berita/peran-indonesia-dalam-menyongsong-poros-maritimdunia.html 